\title{
New Social and Legal Challenges Resulting from the Presence of Islam IN 21 ST CENTURY EURopean Societies
}

\author{
Zoila Combalía \\ University of Zaragoza, Spain \\ combalia@unizar.es
}

COMBALÍA, Zoila. New Social and Legal Challenges Resulting from the Presence of Islam in 21st Century European Societies. International and Comparative Law Review, 2020, vol. 20, no. 2, pp. 113-128. DOI: 10.2478/iclr-2020-0020

\begin{abstract}
Summary: One of the greatest challenges facing the European societies and legal systems arises from the rapid changes that have taken place in recent decades, from a certain level of cultural and religious uniformity towards a landscape of diversity in which Islam has made its presence felt. The viability of coexistence between the Islamic and Western cultures should rest on two foundations: firstly, the acceptance of a common minimum defined by respect for a person's dignity, that is, an agreement on the question of human rights. Along with this consensus there is also a need for respect and the integration of diversity. This study sets out to analyse the challenges that both issues raise..
\end{abstract}

Keywords: Law and interculturality. Human rights in Islam and in the West. Integration of religious diversity in Europe.

\section{Introduction}

One of the greatest challenges facing our society, and, therefore, our legal system, arises from the rapid changes that have taken place in recent decades, from a certain level of cultural and religious uniformity towards a landscape of diversity in which Islam has made its presence felt ${ }^{2}$. The viability of coexist-

1 This article is an updated version of the one I published in Spanish: COMBALÍA, Zoila, Nuevos desafíos sociales y jurídicos derivados de la presencia del Islam en las sociedades occidentales del siglo XXI. La Albolafia: Revista de Humanidades y Cultura, no 4, 2015.

2 According to a study by the Pew Research Center (Available at: https://www.pewforum. org/2017/11/29/europes-growing-muslim-population/. Accessed: 11-01-2021), the number of Moslems in Europe shall increase from approximately 25 million in 2016 (4.9\% of the population) to between 35 and 75 million in 2050, which represents an increase that varies between 5 and 14 percent. The report studies the 28 countries of the EU - including the UK despite Brexit-, and Norway and Switzerland. In particular, the number of Moslems in Spain in the 90s did not reach 200,000, while the current figure is 1,946,300, according to data in the latest official report of the Ministry of Justice regarding religious freedom in Spain (Available at: https://www.mpr.gob.es/mpr/subse/libertad-religiosa/Documents/ InformeAnual/InformeAnual_2017.pdf. Accessed: 11-01-2021) which includes data from 
ence and understanding between the Islamic and Western cultures should in my opinion rest on two foundations: firstly, the acceptance of a common minimum defined by respect for a person's dignity, that is, an agreement on the question of human rights. Along with this consensus there is also a need for respect and the integration of diversity. This study sets out to analyse the challenges that both issues raise.

\section{The consensus over human rights issues ${ }^{3}$}

There is a sector of Western society that has developed a negative image of Islam as a reality that is incompatible with human rights, to a great extent as a result of Islamic fundamentalism, terrorism or the unequal status of women and religious minorities in some countries of the Islamic world.

This censure of human rights is not a unilateral process; voices are also being raised in Islam, denouncing the lack of coherence of the West in defending human rights ${ }^{4}$. Although the UN has been erected as a forum for international consensus on human rights, its role has been questioned in recent decades. Criticisms have been heard that argue that the documents of the UN are westernised ${ }^{5}$ and do not take into account contributions from other cultures ${ }^{6}$. In this context, a

the Observatorio Andalusí of the UCIDE.

3 I published some of the issues considered in this study in: COMBALÍA, Zoila. Secularisation, human rights and women in Islamic societies. In CONTRERAS, Jaime \& MARTÍNEZ DE CODES Rosa M., eds. Trends of Secularism in a Pluralistic World, FrankfurtMadrid, Ed. Vervuert, 2013, pp. 225-240.

4 Huntington wrote that Asian and Islamic countries do not hesitate to highlight the discrepancies between Western theory and practice. "Hypocrisy, double standards, and "but nots" are the price of universalist pretensions. Democracy is promoted, but not if it brings Islamic fundamentalists to power; nonproliferation is preached for Iran and Iraq, but not for Israel; free trade is the elixir of economic growth, but not for agriculture; human rights are an issue for China, but not with Saudi Arabia; aggression against oil-owning Kuwaitis is massively repulsed, but not against non-oil-owning Bosnians. Double standards in practice are the unavoidable price of universal standards of principle." (HUNTINGTON, Samuel P., The Clash of Civilizations and the Remaking of World Order, New York: Simon \& Schuster, 1996).

5 For example, Martín Muñoz comments on the belief in some Islamic sectors "that the Universal Declaration of Human Rights (...) was an ethnocentric product, the participants of which were European states that kept a large part of the Moslem world in a colonial or semi-colonial status, and was an outcome of the Judeo-Christian culture that voluntarily ignored the humanistic contribution of Islam" (MARTÍN MUÑOZ, Gema. La igualdad entre los sexos y la cuestión de los derechos humanos y del ciudadano en el mundo árabe. In MARTÍN MUÑOZ, Gema \& MESSAOUDI, Jalida (eds.), Mujeres, democracia y desarrollo en el Magreb, Madrid: Ed. Fundación Pablo Iglesias, 1995, p. 15.

6 In order to work against the belief that the Universal Declaration of Human Rights is a "Westernised" document, The UN has developed a number of initiatives such as the seminar organised by the Office of the High Commissioner for Human Rights in collaboration with the OIC, with the title: Enriching the universality of human rights. Islamic perspectives on the Universal Declaration of Human Rights. The seminar highlighted the fact that the 
movement arose that set out to show the world that there is an Islamic identity of human rights, a way of conceiving them that is genuine, different and even prior to Western affirmations ${ }^{7}$. To further highlight these declarations, some Islamic organisations have enacted a series of documents on human rights $^{8}$, the most emblematic of which was the Cairo Declaration of Human Rights in Islam of the Organisation of Islamic Cooperation in $1990^{9}$.

\subsection{The legal basis of human rights in Islam and in the West}

When making a comparative analysis, the first thing that calls one's attention is the different foundations on which human rights rest in Islamic and Western texts. Thus, unlike the secular bent of many Western texts, many of the Islamic declarations use a religious reasoning. As I mentioned in another study ${ }^{10}$, "it is not a question of mere formal confessionality - they start and end by invoking Allah and the Prophet-, but rather of a material nature; in other words they establish that 'the rights and freedoms in the Islamic system are not natural rights but rather divine gifts supported by the provisions of the Sharia and Islamic faith' ${ }^{11}$. This is patently expressed in certain declarations in which each and every recognised right and freedom is supported by a literal quotation of the

Declaration is generally valued as an important achievement of humanity, but that it needs to be considered in a way in which cultural diversity is respected, even more so when most of humanity was not present when it was prepared. The published conclusions state that Moslem communities will cooperate with any international initiative, as long as they are invited to do so as equals, but they will reject any project that obliges them to renounce their identity. Along the same lines, the Resolution of the OIC adopted on the 50th anniversary of the Declaration, called for "respect for the main legal systems in the world, including the Islamic model" as something "essential for promotion of broader understanding and the universality of the UDHH" (Resolution no. 51/8-P (IS) on coordination between members states in the area of human rights).

7 "Ces déclarations visaient en premier lieu à réaffirmer une identité islamique qui en fut pas prise en considération dans les débats de l'ONU depuis 1948. Ainsi, elles rappellent que toute législation vient de Dieu, seul détenteur de la souveraineté et que, par conséquent tout droit humain ne peut être évalué qu’au regard de la Loi (i.e. la Sharia) Cependant, elles tentent de ne pas rompre totalement avec les déclarations 'universelles'. Rappelant que l'islam a assuré, bien avant les philosophes des Lumières, les garanties individuelles affirmées par la Révolution française..." (BOTIVEAU, Bernard. Democratie et droits de l'homme: mises en perspective islamistes. In MARTÍN MUÑOZ, Gema (ed.), Democracia y Derechos Humanos en el Mundo Arabe. Madrid: Ed. Cultura Hispánica, 1993, p. 78). See also in this regard: ARZT, Donna E., I diritti religiosi dell'uomo negli Stati musulmani del Medio Oriente e dell'Africa del Nord. Coscienza e Libertà , 1996, n 27, pp. 138-140.

8 Cf. some of these documents in the appendices of COMBALÍA, Zoila, El derecho de libertad religiosa en el mundo islámico, Pamplona: Navarra Gráfica Ed., 2001.

9 Adopted by the 19th Islamic Conference of Ministers of Foreign Affairs, held in Cairo from 31 July to 4 August 1990.

10 COMBALÍA, Zoila, Los ordenamientos europeos ante las minorías musulmanas: aproximación al estudio de los derechos humanos en las declaraciones islámicas. Anuario de Derecho Eclesiástico del Estado, 1998, n 12, pp. 484 onwards.

11 Kuwait Symposium, no.10 of chapter 1. 
Quran or in a hadiz"12. In Islam, human rights are born from the conception of a person as a religious being who has to account for himself and his works before Allah and that, in order to meet his obligations, he receives from the Creator the rights and liberties that permits him to comply with divine will ${ }^{13}$.

The declaration of the Sharia as a basis for human rights does not include the notion that its recognition is limited to Moslems; these rights extend to all individuals, but with the causes, scope and limits established by Islamic religious $\mathrm{law}^{14}$. The statement of the Islamic Council of Europe (ICE) is illustrative in this regard: Universal Islamic Declaration of Human Rights.

\subsection{The inseparable link between rights and duties: special reference to the con-} flicts between freedom of expression and religious freedom

The first consequence of the above statements is that the Islamic world view does not understand the rights and freedoms of the individual without reference to their duties and obligations; it is a human being's responsibility before God that leads to such rights being granted. Al-Ansari declared that adherence to this is in itself an obligation that derives from the mandate to do good and avoid evil that in Islam is based on the following precepts of the Quran: "And let there be [arising] from you a nation inviting to [all that is] good, enjoining what is right and forbidding what is wrong, and those will be the successful" (Quran, 3, 104) ${ }^{15}$.

12 Cf. the Declaration of the Islamic Council of Europe of 1981.

13 According to some Moslem scholars, the Islamic concept of rights, unlike Western ones, is not based on the idea of liberation, but on the requirement of balance (RAMADAN, Tariq. Islam, le face à face des civilisations, Jordan. 1996, pp. 153 onwards.). See also: ALTWAIJRI A.O., Human Dignity in the Light of Islamic Principles. In Publications of the Islamic Educational, Scientific and Cultural Organization, 1999; ABDUR RAHMAN, I. Doi, Shariah. The Islamic Law, London: Ta Ha Publishers, 1984, pp. 422-425.

14 The reason why such rights are recognised for all is expressed in article 1 of the Declaration of the OIC in the following terms: "All human beings form one family whose members are united by their subordination to Allah and descent from Adam. All men are equal in terms of basic human dignity and basic obligations and responsibilities, without any discrimination on the basis of race, colour, language, belief, sex, religion, political affiliation, social status or other considerations. The true religion is the guarantee for enhancing such dignity along the path to human dignity".

Along the same lines, Arkoun states that non-discrimination in terms of the enjoyment of human rights has its grounds in the Sharia, since the Quran proclaims that "We have honoured the sons of Adam" and also the words of the Prophet also contain the following highly significant statements: "There is no merit for an Arab over a non-Arab, nor for a white person over a black person, except in terms of fearing Allah"; "women are the sisters of men" (ARKOUN, Mohamed. Les droits de l'homme en Islam. In MARTíN MUÑOZ, Gema (ed.), Democracia y Derechos Humanos en el Mundo Arabe. Madrid: Ed. Cultura Hispánica, 1993, p. 33).

15 Scholars of the Sharia agree that the observance of what is good and the prohibition of evil, and as a result respect for human rights, is not a recommendation but rather an obligation and an imposition that individuals cannot renounce (Talk by Al-Ansari contained in the summary of the seminar "Enriching the universality of human rights. Islamic perspec- 
This notion of a guarantee for the protection of human rights that is inseparable from responsibilities can be seen in one of the current conflicts in which the Islamic perspective has come into conflict with the Western view; here I refer to the social and legal conflicts brought about by the use of freedom of expression to defame religion or injure religious feelings ${ }^{16}$. Since the fatwa issued by Ayattolah Khomeini against Salman Rushdie on 14 February 1989 for the publication of his book "Satanic Verses"17, names such as Theo Van Gogh, Lars Vilks, the Danish newspaper Jyllands-Posten or the French magazine Charlie Hebdo, have now become sadly famous.

Why do the West and Islam enter into these conflicts? It should be pointed out that both freedom of expression and religious feelings are protected in both cultures and legal systems. But, when they collide with each other, the West suffers particularly because the restriction of certain liberties, such as freedom of expression, which it regards as fundamental to a democratic system, leads it reject any restriction or censure, while Islam feels wounded by the contempt shown by the West towards beliefs that are the essence of its identity, and by the fact that this contempt is enshrined in what they consider to be a "frivolous" exercise of freedom. It could be stated that in such conflicts the West emphasises freedom, -maximum possible freedom, minimum necessary restriction-, while Islam underlines the importance of responsibility.

A prime example of this difference is the text of the Islamic documents that safeguard freedom of expression in terms that are not common in the West.

tives on the Universal Declaration of Human Rights" -HR/IP/SEM/1999, part. I, 15 march 1999-, p. 17. Available at: https://digitallibrary.un.org/record/1490749).

16 For more on this conflict see: COMBALÍA, Zoila. Libertad de expresión y religión en el Derecho comparado. In COMBALÍA, Zoila, DIAGO Pilar and GONZÁLEZ-VARAS, Alejandro (eds.), Libertad de expresión y prevención de la violencia y discriminación por razón de religión, Valencia, Ed. Tirant lo Blanch, 2020; FERREIRO, Juan, Libertad de expresión y sensibilidad religiosa: estudio legislativo y jurisprudencial. Revista General de Derecho Canónico y Derecho Eclesiástico del Estado, 2014, n 35; LÓPEZ SIDRO, Ángel, Libertad de expresión y libertad religiosa en el mundo islámico. Revista General de Derecho Canónico y Derecho Eclesiástico del Estado, 2012, n 30; PALOMINO, Rafael, Libertad de expresión y libertad religiosa: elementos para el análisis de un conflicto. Revista General de Derecho Canónico y Derecho Eclesiástico del Estado, 2012, n 29; PÉREZ-MADRID, Francisca. Incitación al odio religioso o "hate speech" y libertad de expresión. Revista General de Derecho Canónico y Derecho Eclesiástico del Estado, 2009, nº 19.

17 A fatwa is defined as a "a jurisprudential judgement, answer given to a legal question by a specialist in fiqh, explanation that the mufti gives of a law for a specific case". In Shiite Islam, fatwas have special authority (MAILLO SALGADO, Felipe. Diccionario de derecho islámico, Gijón: Ed. Trea, 2005, pp. 79 y 80). The text of the fatwa against Salman Rushdie is as follows: "The author of The Satanic Verses, a text written, edited and published against Islam, against the Prophet of Islam and against the Quran, along with those publishers who are aware of its contents, are sentenced to capital punishment. I invite all brave Muslims from any part of the world to carry out this sentence without delay, so that no one dares to insult the sacred beliefs of Moslems". 
For example, article 12.1 of the ICE Declaration states that "every human being has the right to think and believe and, therefore, to express whatever he thinks and believes without anyone being able to interfere or prohibit it, as long as he remains within the limits prescribed by Islamic law. No one is entitled to disseminate falsehood or to circulate reports which may outrage public decency or slander the Islamic community", adding in paragraph 5 that "respect for the feelings of those who have different religious opinions is one of the virtues of the Moslem. No one has the authority to change another's beliefs or to foment the enmity of society against him"18. In other words, the legitimacy of a freedom of expression used to offend beliefs is not accepted, since it is regarded as a freedom belonging to a society without values.

\subsection{The Sharia as a limit; special reference to women's rights}

A logical consequence of considering that the origin of rights is in the divine plan expressed in the Sharia, is to understand that this also operates as a limit in recognising certain rights that it grants ${ }^{19}$.

The establishment of the Sharia as a limit has been profoundly questioned in the international forums of the UN. Islamic states commonly ratify the Conventions and Treaties on human rights, but when they do, they sometimes state reservations along the lines of: "inasmuch as they are compatible with the Islamic Sharia", which dilutes the scope of the commitment undertaken.

At present, most Islamic countries do not directly apply the Sharia but have their own regulations, but these regulations are often inspired by Islamic law, especially in the area of family and personal law, which as a result has been defined as the "bulwark of the Sharia". The role of the Sharia as a limit has been specifically questioned when it touches on women's rights. Although this study does not set out to provide an in depth analysis of this issue, the question may be posed as to what extent Islamic law is responsible for the infringement of rights that women have to endure in some current regimes and if any progress on this issue is possible.

18 The OIC declarations express themselves in terms very similar to those of the ICE when they state that " 1 . Everyone shall have the right to express his opinion freely in such a manner as would not be contrary to the principles of the Sharia. 2. Everyone shall have the right to advocate what is right,, and propagate what is good, and warn against what is wrong and evil according to the norms of Islamic Sharia. 3. Information is a vital necessity to society. It may not be exploited or misused in such a way as may violate sanctities and the dignity of Prophets, undermine moral and ethical values or disintegrate, corrupt or harm society or weaken its faith. 4. It is not permitted to excite nationalistic or doctrinal hatred or to do anything that may be an incitement to any form of racial discrimination" (article 22).

19 The compatibility of rights with the Sharia is not just one of limits, it is also a reference point for interpreting or clarifying rights. Thus, the Declaration of the OIC concludes by affirming that "all the rights and freedoms stipulated in this Declaration are subject to the Islamic Sharia" (article 24) and that "the Islamic Sharia is the only source of reference for the explanation or clarification of any of the articles of this Declaration" (article 25). 
Moslems believe that the revelations contained in the Quran and the Sunna date from the years 610-632. This was a period in which not only the Arab communities from which Islam arose but societies in general were organised around patriarchal structures of male primacy that were to be the model that inspired the Islamic law enacted in the 7th century. The Quran affirms that men and women have equal dignity as human beings ${ }^{20}$, but it then argues for the primacy of men in the family and in society ${ }^{21}$.

Given that the functions of men and women are not the same, neither are their rights and duties ${ }^{22}$. As such, men are obliged to pay the dowry (mahr) to women when intending to marry ${ }^{23}$ and to maintain them economically (nafaqa) ${ }^{24}$. The woman's rights to a dowry and to being maintained are counterbalanced by her duty to obey her husband and ensure that the home functions well ${ }^{25}$.

20 The Quranic basis for defending equality with regard to human dignity is based on the following verses or surahs that refer to the common origins and nature of men and women. The Quran states: "I will not suffer the work of any of you, whether male or female, to go to waste, each of you is from the other..." $(3,195)$; or: "O mankind, fear your Lord, who created you from one soul and created from it its mate and dispersed from both of them many men and women..." $(4,1)$.

21 This equal human dignity is not expressed in legal terms. Men and women carry out different functions in the family and society and the primary position corresponds to men, as the following surah states: "... And due to the wives is similar to what is expected of them, according to what is reasonable. But the men have a degree over them ..." $(2,228)$.

22 This equal human dignity and differentiation in legal terms can be seen in the OIC declaration that states that "woman is equal to man in human dignity; and has her own rights as well as duties to perform ..." (article 6). For a more detailed explanation of the rights and duties of the parties see: COMBALÍA, Zoila. ¿Igualdad o equidad?: el reconocimiento en Occidente de instituciones islámicas de inspiración patriarcal. In GONZÁLEZ-MORENO, Beatriz (Eds.), Políticas de igualdad y derechos fundamentales. Valencia: Ed. Tirant lo Blanch, 2009, pp. 253-298.

23 For more information about the Islamic dowry see: LIENANT DE BELLEFONDS, Yvon Linant. Traité de Droit musulman comparé, vol. 2, París-La Haya 1965, pp. 199 onwards; MILLIOT Louis and BLANC, François Paul. Introduction à l'étude du droit musulman, París: Ed. Dalloz, 2001, pp. 292 onwards; NASIR, Jamal J. The Islamic Law of Personal Status. The Hague-London-New York: Ed. Kluwer Law International, 2002, pp. 83 onwards; SPIES, Otto, The Encyclopaedia of Islam, vol. VI, 1986, p. 79 onwards.; WANI, Mohammed Afzal, The Islamic Institution of Mahr: A Study of its Philosophy, Workings and Related Legislations in the Contemporary World. Noonamy, Kashmir: Upright Study Home, 1995.

24 For more information about the nafaqa see: LIENANT DE BELLEFONDS, Yvon Linant. Traité de Droit musulman comparé, vol. 2, París-La Haya 1965, pp. 259 onwards; NASIR, Jamal J. The Islamic Law of Personal Status. The Hague-London-New York: Ed. Kluwer Law International, 2002, pp. 97 onwards. These duties of the husband have considerable bases in the Quran. It states with regard to the duty of sustenance, for example, that the husband "should provide their (women's) sustenance and clothing in a fair manner" (2:233).

25 Regarding the access of women to the labour market, the Sharia does not prohibit women from working outside the home. What is more, it expressly establishes that, if she does work, she is entitled to a fair salary just like a man. The Quran states: "for men is a share of what they have earned, for women is a share of what they have earned" $(4,32)$, and some female contemporaries of the Prophet actively participated in politics (see AFSHAR, 
It could be stated that Islamic law, by virtue of its patriarchal inspiration, does not include equality between men and women but rather a state of equity; in other words, the question is not to talk about equal rights and duties but rather complementary ones, and in the Islamic worldview, this complementary approach is what guarantees social harmony.

However, there are now tendencies that defend the idea that full equality between men and women is compatible with Islam. The starting point of these points of view is that when the Sharia was enacted, it meant an advance in the situation of women ${ }^{26}$ and that this is the Islamic spirit that would need to be expressed by adapting it to modern society ${ }^{27}$.

Thus, if Islam did not represent a step backward at that time, but rather an advance, then the problem is not the provisions of the Sharia in their historical context, but rather the literal manner in which they are currently applied. Should the provisions of the Sharia be literally applied or should the principles that inspired them be extracted and adapted to new contexts?

\subsection{Interpretation and application of Islamic law in current social contexts}

The answer to this question, as to whether Islamic law can adapt and modernise, is a highly complex one.

Haleh, Islam and feminism: an analysis of political strategies, in YAMANI, Mai (ed.), Feminism and Islam. Legal and literary perspectives, Berkshire: Ithaca Press, 1997, p. 199). However, while for men work is a legal and religious duty, for women it is an outcome of their decision, as long as it is compatible with caring for the home and children and being obedient to the husband. As regards access to education, Islam defines it as a right and a duty in equal terms for men and women. The declaration of the ICE declares as such when its states that "learning is a right for everyone. The seeking of science is also a an obligation of everyone, men and women". And it bases this declaration on the hadiz or saying of the Prophet: "the seeking for sciences is a divine precept imposed on all male and female Moslems" (article 21).

26 One of the improvements frequently mentioned when discussing the changes in the condition of women under Islam is that it prohibited the infanticide of female babies, which in pre-Islamic Arab societies was not an uncommon practice. The Sharia regulated polygamy, which was habitual in such societies, and established limits (up to four wives) and requirements designed to protect women demanding that the man should treat his wives equally. Repudiation, which was also practiced before Islam, is not prohibited but is regarded as morally reprehensible behaviour; according to a saying attributed to the Prophet, "the most hateful permissible thing to Allah is divorce". Finally, the Islamic provisions on property are worthy of consideration: Islamic marriage does not affect the property and earnings of the parties and the woman may freely dispose of and administer her own property without any intervention or consent from her husband, which was a highly advanced provision for the times in which it was enacted.

27 See another example of this position in CONNORS, Jane. The Women's Convention in the Muslim World. In YAMANI, Mai (ed.), Feminism and Islam. Legal and literary perspectives, Berkshire: Ithaca Press, 1997, p. 364. 
The issue of difficulties for a "modern" interpretation of Islamic law, adapted to modern contexts, is linked to the affirmation that in Islamic law divine revelation, as a source of knowledge, predominates over reason ${ }^{28}$, and to the absence of a sacramental authority in Islam.

While in Christianity revelation, or God speaking to the human being, takes the form of a person (Jesus Christ), who lives on in his church, revelation in Islam is expressed in a book: the Quran, and there is no sacramental authority that can make an authentic interpretation. In other words, Islam is not a church, it has no priesthood; Islam is a community-the umma-; the concept of authority is a moral one, not sacramental, linked to the wisdom and rectitude of whosoever interprets the texts.

In the first three centuries of Islam, there was a great deal of freedom and development of ijtihad or interpretation, but then in the 10th century, faced with the expansion of Islam and the subsequent fear of a break up of the umma and that interpretation would end up squandering the revelation, it was declared that: "the door of ijtihad has been closed"29.

However, although it may be the case that not imposing restrictions on interpretations of the Sharia in the 10th century would have meant a threat to its very survival, nowadays the dangers inherent to the continuing existence of the Sharia are precisely because of its stagnation and consequent inability to resolve the problems that arise in modern society. Furthermore, the contrasts between a law halted in interpretations of the 10th century and the culture of the 21 st may place Moslems in the unpleasant quandary of having to choose between their condition as Moslems or as modern citizens, since both options are irreconcilable. This has led to approaches in which the need for an interpretation of the Sharia adapted to modern life is defended.

It should be highlighted that the underlying problem of Islam is not so much the status of women, religious minorities, etc., but rather one that goes much deeper: the ability of the Sharia to adapt, to be interpreted in line with the evolution of society ${ }^{30}$. This, in my opinion, is one of the major challenges facing Islam today.

28 The idea of a natural law that can be rationally known has hardly been developed in Islamic thinking and law. However, Ferrari has commented that the absence of the notion of natural law does not exclude the possibility in Islam of a substantial convergence between the Sharia and natural law (FERRARI, Silvio. El espíritu de los derechos religiosos. Judaísmo, cristianismo e Islam, Barcelona: Ed. Herder, 2004, p. 175). An example of this convergence are the Islamic Declarations that, as we have seen, recognise basic human rights, although they do so be basing them on the Quran and the Sunna.

29 See Schacht on the factors that led to the progressive restrictions on, and final closure of ijtihad, in SCHACHT, Joseph. An Introduction to Islamic Law, Oxford: Oxford University Press, 1998 reprinted, pp. 69 onwards.

30 A customary affirmation made by scholars of Islamic law is that it is not a divine and immutable system. Such a consideration would lead to confusion between the Sharia, 
Although the debate surrounding the interpretation of Islamic law has become more intense in recent years, it is not something entirely new. Even at the end of the 8th century there were fierce arguments between the rationalist Mu'tazilites and the traditionalists ${ }^{31}$ and throughout history literal interpretations of the Quran that closely follow the text have intertwined with others that have sought a context that enables it to adapt to progress.

One of the modern schools that grants the broadest margin for human interpretation is one based on the consideration that the Quran must be understood not as a text, but rather as a discourse. This is the stance taken by, amongst oth-

especially the sources, and the Fiqh, the methods. The original sources of Islamic law are divine and immutable. The methods of law, i.e. the understanding and application of the Sharia, are human and may change as a result of time and circumstances. On the other hand, while the Sharia covers different aspects of human life (legal, moral, social, spiritual, etc.), the Fiqh refers solely to the legal aspects of the Sharia, which are different from the moral ones,. Proof of the non-immutable nature of the Fiqh is the existence from the first centuries of different legal schools in both the Sunni and Shiite traditions. In modern Islam there are two schools of thought in the interpretation of the Sharia: the traditionalists and the evolutionists. The first school adheres to the interpretations of the Sharia as they are recorded in the classical legal treatises of the 10th century in the different classical schools. The second group, while identifying with the doctrine and methods of classical Islamic law, sets out to make it valid for modern times. See FERRARI, Silvio. El espíritu de los derechos religiosos. Judaísmo, cristianismo e Islam, Barcelona: Ed. Herder, 2004. For a basic explanation of Islamic law see CAPUTO, Giuseppe. Introduzione al Diritto Islamico, I, Torino: Ed. Giapichelli, 1990; COULSON, Noel J. Historia del Derecho islámico, trans. M. Eugenia Eyras, Barcelona: Ed. Bellaterra, 1998; ABDUR RAHMAN, I. Doi, Shariah. The Islamic Law, London: Ta Ha Publishers, 1984; LÓPEZ ORTIZ, José. Derecho musulmán, Barcelona-Buenos Aires: Ed. Labor, 1932; SCHACHT, Joseph. An Introduction to Islamic Law, Oxford: Oxford University Press, 1998 reprinted.

The harmonisation of Islamic law with human rights depends to a great extent on the posture adopted in its interpretation. Some academics maintain that, for a genuinely Islamic interpretation of human rights, it is important to bear in mind that the purpose and aim of the Sharia is to promote human welfare and prevent injury (maslahah). This theory of the purpose and objective of the Sharia in the application of Islamic law guarantees its total equality and is essential in issues of international protection of human rights. This viewpoint is held by, amongst others, BADERIN, Mashood A. International Human Rights and Islamic Law, Oxford: Oxford University Press, 2005, pp. 40 onwards.

31 The Mu'tazilites set out to reconcile Islam with rationalist thinking by leaving a wide margin for interpretation of the Quran using the argument that Allah had imposed the obligation on humanity to use its intellectual powers to grow in knowledge of the truth. See more about this school in GIMARET, Daniel, Mu'tazila. In The Encyclopaedia of Islam, Leiden-New York: Ed. Brill, 1993, vol. VII, pp. 783-793. Ibn Rushd (Averroes) also posed some important considerations about the possibility of harmonising revelation and reason, although the doctrines of al-Ash'ari had a greater influence amongst Moslem jurists, where he stated that "justice is nothing more than the manifestation of the divine will: if an act has been ordered by Allah, it must be just, and if it has been prohibited, it must be unjust, however fair it may appear to man, since only Allah knows what is just or unjust" (in FERRARI, Silvio. El espíritu de los derechos religiosos. Judaísmo, cristianismo e Islam, Barcelona: Ed. Herder, 2004, pp. 164 and 165). 
ers, Abu Zayd, who states that there is room for progress in the understanding of revelation. He wondered why it was necessary to uphold the belief that the scholars of Islam of the first centuries, up to the end of ijtihad, were more qualified than modern authors to develop ideas and thought on religious issues ${ }^{32}$. According to him, although the sacred texts are divine in origin, they are given to human beings, whose purpose is to understand and apply them, and this process of comprehension is human and takes place in different periods and contexts ${ }^{33}$.

The problem surrounding these currents of thought is that they are far from being recognised as "orthodox" by parts of the Moslem world. What is more, the current contexts of confrontation and "clashes of civilisations" have become a breeding ground for entrenchment and political support for the most radical Islamic currents.

\section{Respect for diversity and integration of Islam in Europe}

If one of the main challenges facing Islam today is the interpretation of the Sharia, its capacity to adapt to current social contexts and most especially, to respect human rights, a major challenge for the West is to make space in the European identity for cultural/religious diversity; to not fear the visible face of religion and in particular, the greater visibility of Islam, and promote its insertion into the system.

Islam's entry into Europe has raised questions about the role of secularity. Is secularity an "instrumental" principle at the service of fundamental rights -secularity as a guarantee of a space of freedom, of equal freedom for all in matters of religion-, or should we regard it as an "overriding" principle, to which such rights and freedoms are subordinated ${ }^{34}$.

32 Abu Zayd also comments on the fact that the great Moslem thinkers of the first centuries had connections to the cultures of their age (Greek, Persian, etc.) and wonders why we are scared of having any relation with modern culture (see interview with Abu Zayd in: ABÜ ZAYD, Nasr Hamid, (ORTEGA, Rafael \& VÁZQUEZ, Rocío interviewers). Pliegues de la memoria: Nasr Hamid Abu Zayd, Madrid: Casa Árabe e Instituto Internacional de Estudios Árabes y del Mundo Musulmán, 2010).

33 For example, Abu Zayd has commented on the issue of inheritance and all the aspects relating to women: "We understand that Islam stipulated that women have the right to half of the portion of the man's inheritance, in an age in which women were stopped from inheriting anything, in a social and economic culture in which women were men's mere chattels. The Quran is clear and it is not acceptable to understand that ijtihad should be stopped at the point in which divine revelation halted since by doing so the idea of it being applicable to all ages and places would be destroyed" (quote by Abu Zayd contained in a sentence of the Court of Cairo that declared him an apostate for his thesis on interpreting the Quran, and which therefore dissolved his marriage (Appeal Court of Cairo in case no. 287 of 14 June 1995, against: 1. Nasr Hamid Abu Zayd, 2. Ibtihal Ahmed Kamal Yunis).

34 A paradigmatic example of this model would be the French law of 2004 that impedes students from wearing religious signs, which means that the meaning of a school's neutrality is no longer to guarantee the liberty and equality of the students but in order to further 
The growing secularisation of European society has permitted this situation to develop to the point where there is a certain confinement of religion, towards its reclusion at home, in the conscience and in the place of worship -and this one, if possible, with poor visibility $-{ }^{35}$. However, the appearance of religions such as Islam, with a strong emphasis on identity and a clear presence (headscarves, mosques, minarets, halal food, etc.), has led to questions about the most appropriate course that the relations between law and religion should take to ensure peaceful coexistence.

One hazard inherent in the forced reclusion of religion is that it may be radicalised, while if we arbitrate on its coexistence in society, as part of the system, then it is my view that such a risk can be reduced.

For example, if Islam is taught at school with text books and authorised programs that are compatible with constitutional values, by teaching staff that are qualified and integrated into the centre, etc., then the children receiving it would understand it as something that is part of the legal system and society in which they live. Their feelings may well be very different if they only hear about religion in a prayer room/mosque camouflaged in a garage, from an imam who only speaks Arabic and whose discourses have no point of connection with the inputs that the child receives outside that space. The example of education could be further extended to the provision of places of worship that are recognised and placed within the population and not in industrial estates on the outskirts, or, if they so wish and if there is no justifiable reason for impeding it, wear the headscarf or symbol of their belonging as something normal ${ }^{36}$.

The alternative is that such people, as mentioned above, end up feeling divided between their religious/cultural identity and their identity as citizens, which does not encourage integration in any way, shape or form.

secularity (or neutrality), the rights and equality of students are limited. Law 228/2004, of 15 March, in application of the principle of secularity, establishes that "the use of signs or clothing by which students may ostensibly show religious membership is prohibited in state primary and secondary schools". The law was approved by a large parliamentary majority (the deputies were 494 in favour, 36 against and 31 abstentions).

35 A prime example of this trend to make religion invisible, in this case Islam, was the prohibition on building new minarets in Switzerland in 2009, when there were only four in the whole country.

36 For more on religious symbolism, see: GONZÁLEZ-VARAS, Alejandro. La simbología religiosa en los espacios generales y soluciones concretas en los Estados Europeos. In IGLESIAS, Inés (ed.). Inmigración y Derecho, Valencia: Ed. Tirant lo Blanch, 2006, pp. 249-296; MARTÍNEZ-TORRÓN, Javier. Símbolos religiosos institucionales, neutralidad del Estado y protección de las minorías en Europa, Ius Canonicum, 2014, vol. 54, nº 107, pp. 107-144; ROCA, María J. La jurisprudencia y doctrina alemana e italiana sobre simbología religiosa en la escuela y los principios de tolerancia y laicidad. Crítica y propuestas para el Derecho español, Anuario de Derecho Eclesiástico del Estado, 2007, n 23, pp. 257-291. 
This state of affairs poses a challenge to the West and obliges it to rethink the role of religion in society and the concept of secularity as an instrument at the service of peaceful coexistence and the enjoyment of the same rights for everyone ${ }^{37}$ since, as Tocqueville stated, "despotism may govern without faith, but liberty cannot" 38 .

In this sense, a "despotic" secularism that governs without religion becomes not just a negation of religious freedom but also, given that freedoms are interlinked, of fundamental rights and public freedoms as a whole.

Alongside the dangers of a repressive secularism that impedes the integration of Islam into European societies, a less subtle obstacle has appeared in the form of the alarming increase in platforms -even politically legitimated ones- with decidedly xenophobic tendencies that incite hatred for religious reasons, including but not limited to, the encouragement of Islamophobia.

The question underlying these issues is if it possible to have a simultaneous Islamic and European identity. There is an Afro-Islam, an Asian Islam, even an American Islam, despite the events of 11 September. However, Moslems who maintain their religious identity find it difficult to be regarded as totally European, and sometimes have to opt between being "Moslems without Islam" or "Moslems in Europe outside Europe" 39 .

For all of us to be equal citizens, it is essential on the one hand to not oblige anyone to renounce or conceal their cultural/religious identity, that, with respect for public order and human rights, such identities may be present in society.

We may therefore conclude that one of the major challenges currently facing Islam is, as explained above, if it is able to bring about from within an interpre-

37 "The underlying problem in the modern age is not one of achieving a clear separation between politics and religion, but rather one of guaranteeing the establishment and continuation of a set of peaceful and constructive institutional relations between the public powers and religions in a given civil society, so that the social subjects involved can collaborate in a varied and orderly manner towards the complete welfare of each individual and in the creation of the common good of all society" (GEROSA, Libero, ¿Es inconciliable la identidad laica de los ciudadanos europeos con el monismo islámico?, Valencia, EDICEP, 2010, p. 21).

38 Alexis de Tocqueville, Democracy in America, I, New York: Vintage Books, 1954.

39 RAMADÁN, Tariq. El Islam minoritario. Cómo ser musulmán en la Europa laica, Biblioteca del Islam Contemporáneo, Barcelona: Ed. Bellaterra, 2002, pp. 85 and 86. The approach proposed by this author to bring about progress by creating a combined Islamic and European identity consists of extracting from the primary sources - the Quran and the Sunna - the Moslem essence, eliminating the cultural components that have adhered to it throughout its pilgrimage. He defends the idea that the Islamic system is not static: "Faith needs a spirit and reason that are in a constant state of consciousness and activity (...). For the Moslems living in Europe it is of the highest importance (...) for them to know how to re-read the Islamic message in greater depth in its original life and also acquire a combined vision of the areas, studies and resources at their disposal to deal with the current situation". 
tation of the Sharia that is adapted to current social contexts, in particular the issue of respect for human rights. At the same time, coexistence with Islam has shown the West that it cannot ignore the reality of religion in social life and therefore, the need to consider an inclusive notion of secularity. Furthermore, it faces the challenge of defending rights and liberties, which are the foundations of our society, in a context of diversity, overcoming the fear felt in certain sectors when its exercise takes the form of cultural manifestations that are different, and sometimes disconcerting for the Western model.

\section{List of references}

ABDUR RAHMAN, I. Doi, Shariah. The Islamic Law, London: Ta Ha Publishers, 1984.

ABÜ ZAYD, Nasr Hamid, (ORTEGA, Rafael \& VÁZQUEZ, Rocío interviewers). Pliegues de la memoria: Nasr Hamid Abu Zayd, Madrid: Casa Árabe e Instituto Internacional de Estudios Árabes y del Mundo Musulmán, 2010.

AFSHAR, Haleh, Islam and feminism: an analysis of political strategies, in YAMANI, Mai (ed.), Feminism and Islam. Legal and literary perspectives, Berkshire: Ithaca Press, 1997.

Al-Ansari, in Summary of the seminar "Enriching the universality of human rights. Islamic perspectives on the Universal Declaration of Human Rights" -HR/IP/SEM/1999, part. I, 15 march 1999. Available at: https://digitallibrary.un.org/record/1490749.

ARKOUN, Mohamed. Les droits de l'homme en Islam. In MARTÍN MUÑOZ, Gema (ed.), Democracia y Derechos Humanos en el Mundo Arabe. Madrid: Ed. Cultura Hispánica, 1993.

ARZT, Donna E., I diritti religiosi dell'uomo negli Stati musulmani del Medio Oriente e dell'Africa del Nord. Coscienza e Libertà , 1996, n 27, pp. 138-140.

BADERIN, Mashood A. International Human Rights and Islamic Law, Oxford: Oxford University Press, 2005.

BEARMAN, et al., Encyclopeedia of Islam, 2a. ed., Leiden: E. J. Brill, 1960-2005.

BOTIVEAU, Bernard. Democratie et droits de l'homme: mises en perspective islamistes. In MARTÍN MUÑOZ, Gema (ed.), Democracia y Derechos Humanos en el Mundo Arabe. Madrid: Ed. Cultura Hispánica, 1993.

CAPUTO, Giuseppe. Introduzione al Diritto Islamico, I, Torino: Ed. Giapichelli, 1990.

COMBALÍA, Zoila. Secularisation, human rights and women in Islamic societies. In CONTRERAS, Jaime \& MARTÍNEZ DE CODES Rosa M., eds. Trends of Secularism in a Pluralistic World, Frankfurt-Madrid, Ed. Vervuert, 2013.

- El derecho de libertad religiosa en el mundo islámico, Pamplona: Navarra Gráfica Ed., 2001.

- Libertad de expresión y religión en el Derecho comparado. In COMBALÍA, Zoila, DIAGO Pilar and GONZÁLEZ-VARAS, Alejandro (eds.), Libertad de expresión y prevención de la violencia y discriminación por razón de religión, Valencia, Ed. Tirant lo Blanch, 2020.

CONNORS, Jane. The Women's Convention in the Muslim World. In YAMANI, Mai (ed.), Feminism and Islam. Legal and literary perspectives, Berkshire: Ithaca Press, 1997

COULSON, Noel J. Historia del Derecho islámico, trans. M. Eugenia Eyras, Barcelona: Ed. Bellaterra, 1998 
De Diego, Antonio. Populismo islámico. Cómo se ha secuestrado la espiritualidad musulmana, Córdoba: Ed. Almuzara, 2020.

Kiviorg, Merilin, Secularization of religious freedom: Religion and limits of State control. Granada: Comares, 2020.

FERRARI, Silvio, El espiritu de los derechos religiosos. Judaísmo, cristianismo e Islam, Barcelona: Ed. Herder, 2004.

FERREIRO, Juan, Libertad de expresión y sensibilidad religiosa: estudio legislativo y jurisprudencial, Revista General de Derecho Canónico y Derecho Eclesiástico del Estado, 2014, no 35 .

GEROSA, Libero, ¿Es inconciliable la identidad laica de los ciudadanos europeos con el monismo islámico?, Valencia, EDICEP, 2010.

GIMARET, Daniel, Mu’tazila. In The Encyclopaedia of Islam, Leiden-New York: Ed. Brill, 1993, vol. VII.

GONZÁLEZ-VARAS, Alejandro. La simbología religiosa en los espacios generales y soluciones concretas en los Estados Europeos. In IGLESIAS, Inés (ed.). Inmigración y Derecho, Valencia: Ed. Tirant lo Blanch, 2006, pp. 249-296.

HUNTINGTON, Samuel P. The Clash of Civilizations and the Remaking of World Order, Simon \& Schuster, 1996.

LIENANT DE BELLEFONDS, Yvon Linant. Traité de Droit musulman comparé, vol. 2, París-La Haya 1965.

LÓPEZ ORTIZ, José. Derecho musulmán, Barcelona-Buenos Aires: Ed. Labor, 1932.

LÓPEZ SIDRO, Ángel, Libertad de expresión y libertad religiosa en el mundo islámico. Revista General de Derecho Canónico y Derecho Eclesiástico del Estado, 2012, n 30.

MAILLO SALGADO, Felipe. Diccionario de derecho islámico, Gijón: Ed. Trea, 2005, pp. 79 y 80.

MARTÍN MUÑOZ, Gema. La igualdad entre los sexos y la cuestión de los derechos humanos y del ciudadano en el mundo árabe. In MARTÍN MUÑOZ, Gema \& MESSAOUDI, Jalida (eds.), Mujeres, democracia y desarrollo en el Magreb, Madrid: Ed. Fundación Pablo Iglesias, 1995.

MARTÍNEZ-TORRÓN, Javier. Símbolos religiosos institucionales, neutralidad del Estado y protección de las minorías en Europa, Ius Canonicum, 2014, vol. 54, n 107, pp. $107-144$.

MILLIOT Louis and BLANC, François Paul. Introduction à létude du droit musulman, París: Ed. Dalloz, 2001.

NASIR, Jamal J. The Islamic Law of Personal Status. The Hague-London-New York: Ed. Kluwer Law International, 2002.

PALOMINO, Rafael, Libertad de expresión y libertad religiosa: elementos para el análisis de un conflicto. Revista General de Derecho Canónico y Derecho Eclesiástico del Estado, 2012, n' 29.

PÉREZ-MADRID, Francisca. Incitación al odio religioso o "hate speech" y libertad de expresión. Revista General de Derecho Canónico y Derecho Eclesiástico del Estado, $2009, \mathrm{n}^{\circ} 19$.

RAMADAN, Tariq. Islam, le face à face des civilisations, Jordan, 1996.

- El Islam minoritario. Cómo ser musulmán en la Europa laica, Biblioteca del Islam Contemporáneo, Barcelona: Ed. Bellaterra, 2002.

ROCA, María J. La jurisprudencia y doctrina alemana e italiana sobre simbología religiosa en la escuela y los principios de tolerancia y laicidad. Crítica y propuestas para el Derecho español, Anuario de Derecho Eclesiástico del Estado, 2007, nº 23, pp. 257-291. 
ICLR, 2020, Vol. 20, No. 2.

SCHACHT, Joseph. An Introduction to Islamic Law, Oxford: Oxford University Press, 1998 reprinted.

A. DE TOCQUEVILLE, Democracy in America, I, Vintage Books, New York (1954).

WANI, Mohammed Afzal, The Islamic Institution of Mahr: A Study of its Philosophy, Workings and Related Legislations in the Contemporary World. Noonamy, Kashmir: Upright Study Home, 1995.

HADDAD Yvonne Y. and GOLSON Tyler, Overhauling Islam: representation, construction, and cooption of "Moderate Islam" in Western Europe. In Journal of Church and State, 2007, vol. 49, n. 3, pp. 487-515. 